\title{
Fermented Foods: Are They Tasty Medicines for Helicobacter pylori Associated Peptic Ulcer and Gastric Cancer?
}

\author{
Mydhily R. B. Nairt, Deepak Chouhant, Sourav Sen Gupta and Santanu Chattopadhyay* \\ Microbiome Research Facility, Microbiome Biology, Rajiv Gandhi Centre for Biotechnology, Trivandrum, India
}

\section{OPEN ACCESS}

Edited by:

Jyoti Prakash Tamang,

Sikkim University, India

Reviewed by:

Amedeo Amedei,

University of Florence, Italy

Alejandro Piscoya,

Universidad Peruana de Ciencias

Aplicadas, Peru

*Correspondence:

Santanu Chattopadhyay

santanu@rgcb.res.in

tThese authors have contributed equally to this work.

Specialty section: This article was submitted to Food Microbiology, a section of the journal Frontiers in Microbiology

Received: 31 March 2016

Accepted: 11 July 2016

Published: 25 July 2016

Citation:

Nair MRB, Chouhan D, Sen Gupta S and Chattopadhyay S (2016)

Fermented Foods: Are They Tasty Medicines for Helicobacter pylori Associated Peptic Ulcer and Gastric Cancer? Front. Microbiol. 7:1148. doi: 10.3389/fmicb.2016.01148
More than a million people die every year due to gastric cancer and peptic ulcer. Helicobacter pylori infection in stomach is the most important reason for these diseases. Interestingly, only $10-20 \%$ of the $\mathrm{H}$. pylori infected individuals suffer from these gastric diseases and rest of the infected individuals remain asymptomatic. The genotypes of H. pylori, host genetic background, lifestyle including smoking and diet may determine clinical outcomes. People from different geographical regions have different food habits, which also include several unique fermented products of plant and animal origins. When consumed raw, the fermented foods bring in fresh inocula of microbes to gastrointestinal tract and several strains of these microbes, like Lactobacillus and Saccharomyces are known probiotics. In vitro and in vivo experiments as well as clinical trials suggest that several probiotics have anti-H. pylori effects. Here we discuss the possibility of using natural probiotics present in traditional fermented food and beverages to obtain protection against $H$. pylori induced gastric diseases.

Keywords: fermented food, probiotics, prevention of $\boldsymbol{H}$. pylori infection, peptic ulcer, gastric cancer

\section{INTRODUCTION}

"Let food be thy medicine and medicine be thy food."

Hippocrates $(460$ - 370 BC)

Every year peptic ulcer and gastric cancer takes approximately 301,000 and 740,000 lives, respectively (Piazuelo and Correa, 2013; Naghavi et al., 2015). Although both diseases have multiple etiologies like stress, diet, smoking and host genetic background, Helicobacter pylori infection is perhaps the most critical among them (Malfertheiner et al., 2014). However, every H. pylori infected individual does not develop peptic ulcer or gastric cancer. More than half of the world population is infected by $H$. pylori, but $10-20 \%$ of the infected people suffer from these diseases (Dorer et al., 2009). Why $\sim 80 \%$ of the $H$. pylori infected people in any given population never suffer from gastric disorders is unknown at present. Also, the clinical outcomes among the H. pylori infected population suffering from gastric disorders vary tremendously with geography (Covacci et al., 1999). For example, gastric cancer is fairly common in East-Asian countries like Japan and Korea, but in most African countries and India, the incidence of gastric cancer is low in spite of having high prevalence of $H$. pylori infection (Holcombe, 1992; Singh and Ghoshal, 2006; Shiota et al., 2013). Variations in bacterial and human genetic factors have been linked to explain the 
differences in clinical outcome, but our understanding of $H$. pylori infection and related diseases are really incomplete.

Microbiota is the ecological community of commensal, symbiotic and pathogenic microorganisms that literally share our body space. Microbiome is the combined genomes of the microbiota (Lederberg, 2001). Recent metagenomic analyses of DNA isolated from gastric tissue specimens show that human stomach is the niche of many bacterial species (MaldonadoContreras et al., 2011). While the exact significance of the microbes that co-exist in highly acidic gastric milieu is not understood till date, it seems apparent that $H$. pylori infection can alter the dynamics of gastric microbiota (Andersson et al., 2008). However, microbiota can also be modulated by several other factors like alteration in immunity due to other infections and change in lifestyle including food and beverage consumptions (De Filippo et al., 2010). Interestingly, almost every geographical location has unique tradition of consuming fermented foods and beverages (Campbell-Platt, 1987). These fermented foods are rich source of bacteria, yeasts and molds and many of these microbes provide benefits to hosts and act as probiotics (Tamang et al., 2016a,b). More intriguingly, adding purified probiotics to therapy against $H$. pylori gives better eradication rate and reduces the side effects of antibiotics (Zhang et al., 2015). Unfortunately, however, the significances of the natural probiotics in traditional fermented foods and beverages are less studied in the context of H. pylori associated diseases. In this mini-review, we will discuss how probiotics present in different fermented foods and beverages may have a role in preventing $H$. pylori related gastric diseases.

\section{H. pylori INFECTION AND GASTRIC DISEASES}

Presence of spiral bacilli in stomach have been reported several times during the past century, but the culture of this slow growing species remained unsuccessful until a serendipitous prolonged incubation of human gastric specimens in microaerophillic conditions during Easter holidays by Barry James Marshall and John Robin Warren (Doenges, 1938; Freedberg and Barron, 1940; Warren and Marshall, 1983; Marshall and Warren, 1984). To prove Koch's postulate Barry Marshall drank pure culture of $H$. pylori, which resulted in hypochlorhydric vomiting and gastritis before he was treated with antibiotics (Marshall et al., 1985). Subsequently, a huge number of studies confirmed the role of $H$. pylori virulence factors in peptic ulcer and gastric cancer and $H$. pylori was classified as a type I carcinogen by WHO (Malfertheiner et al., 2014).

H. pylori expresses many virulence factors, but two multitasking proteins, the vacuolating cytotoxin (VacA) and the cytotoxin-associated gene A (CagA), seem to play the most crucial role in developing the gastro-duodenal diseases. The VacA is a secreted toxin, which forms large cytoplasmic vacuoles inside the host cells (Leunk et al., 1988). The VacA is also involved in reducing mitochondrial transmembrane potential, releasing cytochrome $c$, inducing cell death, activating MAPkinases and inhibiting T-cell activation (Galmiche et al., 2000;
Gebert et al., 2003; Willhite and Blanke, 2004; Yamasaki et al., 2006; Torres et al., 2007). The vacA gene has mosaic structures viz. s1/s2 alleles (encoding signal peptides), $\mathrm{m} 1 / \mathrm{m} 2$ alleles (encoding mid-regions) and i1/i2/i3 (encoding intermediate regions) (Cover et al., 1994; Atherton et al., 1995, 1999; Rhead et al., 2007). The s1 and the il alleles of $v a c A$ are associated with aggressive clinical outcomes (Rhead et al., 2007; Yamaoka, 2010). The $H$. pylori strains carrying vacA s1 usually carry cagA gene, which is located in the cag-pathogenicity island (Blaser et al., 1995; Xiang et al., 1995; Yamaoka, 2010). The $\mathrm{cagA}^{+}$strains are associated with more severe diseases in most regions (Blaser et al., 1995). The cagA gene shows length polymorphism at the $3^{\prime}$ end and this variable region encodes EPIYA motifs that undergo phosphorylation once the CagA protein is translocated into the host cells (Yamaoka et al., 1998; Higashi et al., 2002). The phospho-CagA interacts and deregulates the SHP-2 protein, which leads to cancer, but the CagA can hijack cellular pathways also by phosphorylation independent manner (Higashi et al., 2002; Hatakeyama, 2014).

Polymorphisms in host immune genes also contribute to determine the clinical status of the host (Datta De and Roychoudhury, 2015). For example, polymorphisms in interleukin-1 (IL1) and tumour necrosis factor (TNF) genes have been shown to play important roles in progression of gastric diseases among Scottish, Japanese, American, and Indian populations (El-Omar, 2001; Datta De and Roychoudhury, 2015). Moreover, every geographic region has unique lifestyle including food and beverage intakes, which are known to have effects on gut microbiota (De Filippo et al., 2010).

It is now appreciated that human stomach microbiota consists of 44 bacterial phyla, dominated by four phyla: Proteobacteria, Firmicutes, Actinobacteria, and Bacteroidetes (MaldonadoContreras et al., 2011). A study using Swedish patients showed that the presence of $H$. pylori in stomach may significantly alter the relative abundance of other bacteria (Andersson et al., 2008). Colonization by specific groups of bacteria seems to correlate with $H$. pylori infection status. $H$. pylori colonization dramatically reduced the diversity and increased the colonization of Proteobacteria. Positive H. pylori status in America is also associated with increased abundance of Proteobacteria, Spirochetes and Acidobacteria, and with decreased abundance of Actinobacteria, Bacteroidetes and Firmicutes (MaldonadoContreras et al., 2011). Recently, in mouse, it has been shown that $H$. pylori colonization can influence both gastric and intestinal microbiota (Kienesberger et al., 2016). While it appears that the stomach and intestinal microbiota in the presence and in the absence of $H$. pylori infection may have a role in gastric diseases the mechanism is not known.

Treatment for all $H$. pylori infections has been recommended for several geographical locations (Shiota et al., 2013; Malnick et al., 2014). The usual treatment regimen for $H$. pylori is a short course of two antibiotics (mostly clarithromycin and amoxicillin) along with proton pump inhibitors (e.g., omeprazole or lansoprazole). The treatment, however, is complicated by several factors like bacterial resistance to antibiotics, re-infection, side effects (bloating, diarrhea and taste disturbances) and alteration of healthy gut microbiota (Malnick et al., 2014; 
Zhang et al., 2015). The destruction of the commensal flora may lead to increased prevalence of opportunistic pathobionts, like Clostridium difficile (Malnick et al., 2014). Hence, the treatment of $H$. pylori using antibiotics has the risk for microbiota imbalance or dysbiosis, which may lead to other diseases. Also, eradication of $H$. pylori may lead to esophageal cancer (Blaser, 2008; Blaser and Falkow, 2009). Therefore, alternative approach that can eradicate or prevent $H$. pylori infection without affecting gut microbiota is needed.

\section{USE OF PROBIOTICS FOR THE ERADICATION OF H. pylori}

Probiotics (means 'for life') are live microorganisms which provide beneficial effects when taken in sufficient quantity. Examples include several species of Lactobacillus, Bifidobacterium, Enterococcus, Lactococcus, Streptococcus as well as Saccharomyces (Reid, 1999; Fijan, 2014). Probiotics are known to have beneficial roles in curing antibiotic associated diarrhea, constipation, traveler's diarrhea, food allergies and cancer (McFarland, 2007; Chmielewska and Szajewska, 2010; Hempel et al., 2012; Isolauri et al., 2012; Russo et al., 2014).

Lactobacillus is normally present in human intestinal tract including stomach and it is tolerant to acid and bile (Ruiz et al., 2013). Therefore, Lactobacillus is an attractive candidate for probiotic for the treatment of $H$. pylori related gastric diseases. Bhatia et al. (1989) showed that the culture supernatant of Lactobacillus acidophilus inhibits $H$. pylori in vitro due to an extracellular secretory product. Direct application of L. acidophilus on blood agar plate can also inhibit H. pylori (Vilaichone et al., 2002). Subsequently, it was found that both L. acidophilus and L. casei subsp. rhamnosus can inhibit H. pylori due to the production of lactic acid (Midolo et al., 1995; Enany and Abdalla, 2015). The lactic acid produced by $L$. casei strain Shirota inhibits $70 \%$ of urease activity in vitro and significantly reduces the levels of $H$. pylori colonization in mouse model (Sgouras et al., 2004). Lorca et al. (2001) studied antibacterial activity of 17 Lactobacillus strains on $10 \mathrm{H}$. pylori strains and concluded that the inhibition was due to acid production. They also found that autolysis of $L$. acidophilus after $24 \mathrm{~h}$ of culture releases a proteinaceous compound and this event is related to the bactericidal effect (Lorca et al., 2001). Furthermore, H. pylori colonized mice when treated with a commercial mixture of live probiotics (L. rhamnosus, strain R0011, and L. acidophilus, strain R0052) they suppressed colonization of $H$. pylori strain SS1 (Johnson-Henry et al., 2004).

The sulfatide-binding protein of the $L$. reuteri competes and binds to the gangliotetraosylceramide (asialo-GM1) and sulfatide, which are putative receptors of $H$. pylori (Mukai et al., 2002). Weissella confusa can inhibit $H$. pylori adherence to human gastric cell line by $90 \%$. (Nam et al., 2002).

H. pylori infected MKN45 cells showed increased expression of Smad7 and NFkB, and induced pro-inflammatory cytokines IL- 8 and TNF- $\alpha$ in vitro. Probiotic L. acidophilus pre-treatment, however, inactivate the $S \operatorname{mad} 7$ and $\mathrm{NFkB}$ pathways and reduces the H. pylori induced inflammation (Yang et al., 2012). Using gnotobiotic murine model, it was shown that $L$. salivarius infection also inhibits the colonization of $H$. pylori and associated inflammatory responses like IL-8 release (Kabir et al., 1997; Avía et al., 1998).

Since in vitro experiments and in vivo mouse studies showed promising results, a significant number of clinical trials have been performed in the recent past (Table 1). Several metaanalyses published in 2013 revealed that addition of probiotics in triple therapy against $H$. pylori improves overall efficacy and reduces the side effects of therapy like nausea, diarrhea metallic taste, abdominal/epigastric pain (Ruggiero, 2014). However, it needs further improvement since the benefits conferred by the probiotics are often not too remarkable. For example, a meta-analysis based on literature search strategy suggest that use of probiotics (mostly Lactobacillus, Bifidobacterium and Streptococcus and in few trials Enterococcus, Clostridium, Saccharomyces etc) in triple therapy improve eradication rate of $H$. pylori by $\sim 10 \%$ and reduce adverse effects of therapy by $\sim 15 \%$ (Zhang et al., 2015).

\section{ROLE OF FERMENTED FOODS AND BEVERAGES AGAINST $H$. pylori ASSOCIATED DISEASES}

Fermentation of food dates back to the early ages of human evolution and provides an effective way of preserving food for longer durations (McGovern et al., 2004). Many of the bacteria, yeasts and molds that are present in fermented foods and beverages are known probiotics and probably provide health benefits when consumed raw (Stanton et al., 2005). The significance of the microbes present in fermented food in maintaining human health was first noticed by Elie Metchnikoff (Mackowiak, 2013). He hypothesized that the long and healthy lives of Bulgarian peasants were due to the regular consumption of sour milk and yogurt containing the necessary beneficial microbes (Mackowiak, 2013).

Many of the probiotic that are isolated directly from the fermented foods, particularly fermented dairy products, have anti H. pylori effects. Based on dietary interviews it was found that yogurt, but not unfermented dairy products, when consumed one serving per week or more has protective effect against H. pylori infection in Mexican population (Ornelas et al., 2007). Several strains of Lactobacilli and two strains of yeast directly isolated from yogurt were found to have inhibitory effect on H. pylori (Oh et al., 2002). A meta-analysis of randomized controlled trials shows that there is $\sim 10 \%$ improvement in eradication rates when using fermented milk based probiotics, which seems to be better than capsule/sachet-based bacteriaonly preparations (Sachdeva and Nagpal, 2009). Similarly, 4-week treatment with $L$. gasseri-containing yogurt improved the efficacy of triple therapy in patients with $H$. pylori infection (Deguchi et al., 2012). Another study showed that $H$. pylori infected children have a lower number of Bifidobacterium in their gut, but intake of probiotics-containing yogurt had multiple effects like, restoration of Bifidobacterium, reduction of $H$. pylori load, increase in IgA and decrease in IL-6 (Yang and Sheu, 2012). Three 
TABLE 1 | Some of the anti-Helicobacter pylori clinical trials and meta-analyses that used probiotics.

\begin{tabular}{|c|c|c|c|}
\hline Study & Species & Results & Reference \\
\hline Meta-analysis & Lactobacillus strains & Improvement in eradication rates & Zheng et al., 2013 \\
\hline Randomized open label clinical study & Bifidus infantis & Used as adjuvant improves cure rate & Dajani et al., 2013 \\
\hline Meta-analysis & Lactobacillus and Bifidobacterium species & $\begin{array}{l}\text { Beneficial effects on eradication rate and } \\
\text { incidence of side effect }\end{array}$ & Wang et al., 2013 \\
\hline Meta-analysis & $\begin{array}{l}\text { Lactobacillus acidophilus, Lactobacillus } \\
\text { casei DN-114001, Lactobacillus gasseri, } \\
\text { Bifidobacterium infantis } 2036 .\end{array}$ & Increases eradication rates & Dang et al., 2014 \\
\hline Clinical trials & Lactobacillus gasseri OLL2716(LG21) & $\begin{array}{l}\text { Supression of } H \text {. pylori, reduction in gastric } \\
\text { mucosal inflammation }\end{array}$ & Sakamoto et al., 2001 \\
\hline $\begin{array}{l}\text { Double blind randomized } \\
\text { placebo-controlled crossover clinical study }\end{array}$ & Lactobacillus reuteri strain SD2112 & $\begin{array}{l}\text { Suppression of urease activity and } H \text {. pylori } \\
\text { density }\end{array}$ & Imase et al., 2007 \\
\hline Double blind placebo-controlled study & Lactobacillus reuteri ATCC 55730 & $\begin{array}{l}\text { Suppresses H. pylori infection, decreases } \\
\text { the occurrence of dyspeptic symptoms }\end{array}$ & Francavilla et al., 2008 \\
\hline Double blind placebo-controlled study & Lactobacillus reuteri ATCC 55730 & $\begin{array}{l}\text { H. pylori eradicated in half of the patients by } \\
\text { omeprazole plus } L \text {. reuteri }\end{array}$ & Saggioro et al., 2005 \\
\hline $\begin{array}{l}\text { Double blind randomized } \\
\text { placebo-controlled study }\end{array}$ & $\begin{array}{l}\text { Lactobacillus reuteri DSM 17938, } \\
\text { Lactobacillus reuteri ATCC PTA } 6475\end{array}$ & $\begin{array}{l}\text { Combination of both strains alone exert an } \\
\text { inhibitory effect and when used with } \\
\text { eradication therapy reduces side effects }\end{array}$ & Francavilla et al., 2014 \\
\hline Open label single center study & Lactobacillus reuteri DSM 17938 & Reduction of urease activity & Dore et al., 2014 \\
\hline $\begin{array}{l}\text { Single center, double-blind, prospective, } \\
\text { randomized, placebo-controlled trial }\end{array}$ & Lactobacillus GG & $\begin{array}{l}\text { Reduced side effects and overall treatment } \\
\text { tolerability }\end{array}$ & Armuzzi et al., 2001 \\
\hline
\end{tabular}

strains of lactic acid bacteria, LY1, LY5 AND IF22, which are from the spent culture supernatant of fermented milk, showed anti- $H$. pylori effect (Lin et al., 2011). In china, several probiotics from traditional fermented foods were isolated and two strains of Lactobacillus- L. plantarum 18 and L. gasseri showed potential anti-H. pylori activity (Chen et al., 2010). Kefir, a fermented milk product was found to be effective in eradication and reducing side effects when used along with triple therapy (Bekar et al., 2011). An in vitro study proved that L. plantarum (MLBPL1) isolated from sauerkraut (fermented cabbage) had an anti-Helicobacter activity (Rokka et al., 2006). Interestingly, the main inhibitory activity is mostly associated with cell wall.

Unfortunately, however, anti-H. pylori activity alone does not ensure protection from gastric diseases and gastric cancer may sometimes develop even after eradication of $H$. pylori since some of the $H$. pylori proteins like CagA may act by 'hit and run' mechanism (Shiota et al., 2013; Hatakeyama, 2014). More interestingly, prevalence of $H$. pylori and incidence of gastric diseases does not match in some countries. In Africa and India, the prevalence of $H$. pylori infection and associated gastritis is high, but the incidence of gastric cancer is very low (Holcombe, 1992; Singh and Ghoshal, 2006). On the other hand, East-Asian countries like Japan and Korea have high rates of gastric cancer (Singh and Ghoshal, 2006). Genotype alone cannot be responsible to explain the clinical outcome since nearly all H. pylori strains isolated from East-Asia are virulent (Shiota et al., 2013). Therefore, it is intriguing to compare the microbes that are present in traditional fermented foods and beverages of Japan or Korea and African countries (Table 2). Apparently, fermented foods in African countries are based on milk, beans, grains and roots. They are dominated by Lactobacillus and other lactic acid bacteria. Conversely, Japanese fermented foods are primarily based on rice, soy and fish and these foods have varieties of bacteria and fungi. Interestingly, the soy foods may reduce the risk for gastric cancer, while high salt containing foods might be a risk factor in Japan and Korea (Hirayama, 1981; Woo et al., 2013).

A similar comparison would be exiting between the fermented foods of ethnic populations in North-Eastern India (e.g., ethnic populations in Sikkim state like Bhutias) and Mid-Eastern India (e.g., ethnic population of Jharkhand and West Bengal states like Santhals). North-Eastern states have highest incidence of gastric cancer in India (Pradhan et al., 2003-2004). This high prevalence has been thought to be due to smoking and high salt consumption that possibly come from fermented and pickled foods including fish and meat (Phukan et al., 2005; Verma et al., 2012). Recent analyses of some of the fermented foods showed presence of huge microbial variety but their significances in gastric diseases have not been studied (Tamang and Sarkar, 1996; Tamang et al., 2016a,b). Unfortunately, not much is known about the microbes that are present in fermented foods consumed by the Santhals. But interestingly, they regularly consume intoxicating alcoholic beverages like Handia and Mahua fermented in traditional way and these beverages are not common elsewhere (Kumar and Rao, 2007). Among Santhals, infections with virulent $H$. pylori strains are extremely common without any manifestation of gastric diseases (Datta et al., 2003).

Our current understandings of microbes present in the ethnic fermented foods are incomplete at present, but with modern methodologies like metagenomic analysis using Nextgeneration sequencing the microbial species are now easy to identify (Mozzi et al., 2013). However, to prove or disprove the hypothesis-whether or not microbes present in the ethnic fermented food can protect certain population from peptic ulcer or gastric cancer is very tricky, particularly when $H$. pylori infection is not the only determinant in precipitating the 
TABLE 2 | Microbes present in traditional fermented foods and beverages in Japan and Africa.

\begin{tabular}{|c|c|c|c|c|c|}
\hline $\begin{array}{l}\text { Fermented } \\
\text { food }\end{array}$ & Ingredients & Microorganism & $\begin{array}{l}\text { Known probiotics or } \\
\text { anti-H. pylori } \\
\text { activity }\end{array}$ & Country & Reference \\
\hline \multicolumn{6}{|c|}{ Fermented food of Japan and Korea } \\
\hline Sake & Rice & $\begin{array}{l}\text { Aspergillus sojae, Bacillus subtilis } \\
\text { and lactic acid bacteria }\end{array}$ & $\begin{array}{l}\text { Lactic acid bacteria and } \\
\text { Bacillus subtilis }\end{array}$ & Japan & Sakaguchi, 1958a,b \\
\hline Narezushi & Fish, salt and cooked rice & L. plantarum and L. brevis & L. plantarum & Japan & Kiyohara et al., 2012 \\
\hline Takju & Rice & $\begin{array}{l}\text { Lb. harbinensis, Lb. parabuchneri } \\
\text { Lactobacillus (Lb.) paracasei, Lb. } \\
\text { plantarum, and Leuconostoc } \\
\text { pseudomesenteroides }\end{array}$ & L. plantarum & Korea & Kim et al., 2010 \\
\hline Vinegar & Rice & $\begin{array}{l}\text { Aspergillus oryzae, Lactobacillus } \\
\text { acetotolerance, Acetobacter } \\
\text { pasteurianus, Saccharomyces sp. } \\
\text { and lactic acid bacteria }\end{array}$ & $\begin{array}{l}\text { Lactic acid bacteria and } \\
\text { Saccharomyces sp. }\end{array}$ & Japan & Haruta et al., 2006 \\
\hline Natto & Soybean & Bacillus subtilis & Bacillus subtilis & Japan & Kubo et al., 2011 \\
\hline $\begin{array}{l}\text { Starch } \\
\text { Noodle }\end{array}$ & $\begin{array}{l}\text { Starch from sweet potato, } \\
\text { mung bean etc }\end{array}$ & L. casei, L. cellobiosus, L. fermenti & L. casei & $\begin{array}{l}\text { Korea, } \\
\text { Japan }\end{array}$ & Rhee et al., 2011 \\
\hline Kimchi & $\begin{array}{l}\text { Korean cabbage, radish, } \\
\text { various vegetables, salt }\end{array}$ & $\begin{array}{l}\text { L. mesenteroides, L. brevis, L. } \\
\text { plantarum }\end{array}$ & L. plantarum & Korea & Rhee et al., 2011 \\
\hline Miso & $\begin{array}{l}\text { Soybean and sometime } \\
\text { rice or barley }\end{array}$ & $\begin{array}{l}\text { Aspergillus oryzae Saccharomyces } \\
\text { cerevisiae and lactic acid bacteria }\end{array}$ & $\begin{array}{l}\text { Lactic acid bacteria and } \\
\text { Saccharomyces sp. }\end{array}$ & Japan & Hirayama, 1981 \\
\hline $\begin{array}{l}\text { Komesu } \\
\text { and kurosu }\end{array}$ & Rice & $\begin{array}{l}\text { Aspergillus oryzae, Saccharomyces } \\
\text { cerevisiae and acetic acid bacteria }\end{array}$ & Saccharomyces sp. & Japan & Nanda et al., 2001 \\
\hline Tempeh & Soybean & Rhizopus sp. & $?$ & Japan & Aoki et al., 2003 \\
\hline \multicolumn{6}{|c|}{ Fermented food of Africa } \\
\hline Rigouta & Milk & $\begin{array}{l}\text { Lactococcus lactis and } \\
\text { Enterococcus faecalis }\end{array}$ & Enterococcus faecalis & Tunisia & Ghrairi et al., 2004 \\
\hline Wara & Cow milk & $\begin{array}{l}\text { Lactobacillus plantarum and other } \\
\text { lactic acid bacteria }\end{array}$ & $\begin{array}{l}\text { Lactobacillus plantarum and } \\
\text { other lactic acid bacteria }\end{array}$ & Nigeria & Olasupo et al., 1997 \\
\hline Ugba & Oil bean seed & Bacillus subtilis & Bacillus subtilis & Nigeria & Olasupo et al., 1997 \\
\hline Fufu & Cassava & $\begin{array}{l}\text { Lactobacillus plantarum and other } \\
\text { lactic acid bacteria }\end{array}$ & $\begin{array}{l}\text { Lactobacillus plantarum and } \\
\text { other lactic acid bacteria }\end{array}$ & Nigeria & Olasupo et al., 1997 \\
\hline Ogi & Maize & $\begin{array}{l}\text { Lactobacillus plantarum and other } \\
\text { lactic acid bacteria }\end{array}$ & $\begin{array}{l}\text { Lactobacillus plantarum and } \\
\text { other lactic acid bacteria }\end{array}$ & Nigeria & Olasupo et al., 1997 \\
\hline Kunu-zarki & Millet & $\begin{array}{l}\text { Lactobacillus plantarum and other } \\
\text { lactic acid bacteria }\end{array}$ & $\begin{array}{l}\text { Lactobacillus plantarum and } \\
\text { other lactic acid bacteria }\end{array}$ & Nigeria & Olasupo et al., 1997 \\
\hline Kenkey & Maize & $\begin{array}{l}\text { Lactobacillus plantarum and other } \\
\text { lactic acid bacteria }\end{array}$ & $\begin{array}{l}\text { Lactobacillus plantarum and } \\
\text { other lactic acid bacteria }\end{array}$ & Nigeria & Olasupo et al., 1997 \\
\hline Iru & African locust bean & $\begin{array}{l}\text { Lactobacillus plantarum and other } \\
\text { lactic acid bacteria }\end{array}$ & $\begin{array}{l}\text { Lactobacillus plantarum and } \\
\text { other lactic acid bacteria }\end{array}$ & Nigeria & Olasupo et al., 1997 \\
\hline Garri & Cassava & $\begin{array}{l}\text { Yeast, Lactobacillus plantarum, } \\
\text { Leuconostoc fallax, Lactobacillus } \\
\text { fermentum and other lactic acid } \\
\text { bacteria }\end{array}$ & $\begin{array}{l}\text { Lactobacillus plantarum and } \\
\text { other lactic acid bacteria }\end{array}$ & $\begin{array}{l}\text { Nigeria and } \\
\text { other part } \\
\text { of Africa }\end{array}$ & Kostinek et al., 2005 \\
\hline Kule naoto & Milk & $\begin{array}{l}\text { Lactobacillus plantarum and other } \\
\text { lactic acid bacteria }\end{array}$ & $\begin{array}{l}\text { Lactobacillus plantarum and } \\
\text { other lactic acid bacteria }\end{array}$ & $\begin{array}{l}\text { Maasai in } \\
\text { Kenya }\end{array}$ & Mathara et al., 2004 \\
\hline Poto Poto & Maize dough & $\begin{array}{l}\text { Lactobacillus plantarum, Bacillus } \\
\text { sp., Lactobacillus reuteri, } \\
\text { Lactobacillus casei and other lactic } \\
\text { acid bacteria }\end{array}$ & $\begin{array}{l}\text { Lactobacillus plantarum, } \\
\text { Lactobacillus reuteri, } \\
\text { Lactobacillus casei }\end{array}$ & Congo & Abriouel et al., 2006 \\
\hline Degue & Pearl millet dough & $\begin{array}{l}\text { Lactobacillus plantarum, Bacillus } \\
\text { sp., Lactobacillus reuteri, } \\
\text { Lactobacillus casei, other lactic } \\
\text { acid bacteria and yeast and molds }\end{array}$ & $\begin{array}{l}\text { Lactobacillus plantarum, } \\
\text { Lactobacillus reuteri, } \\
\text { Lactobacillus casei }\end{array}$ & $\begin{array}{l}\text { Burkina } \\
\text { Faso }\end{array}$ & Abriouel et al., 2006 \\
\hline
\end{tabular}

gastric diseases (Parekh et al., 2014; De and Roychoudhury, 2015). How the microbes present in the ethnic fermented food can alter the pathogenicity of $H$. pylori in combination with gastric and duodenal microbiome as well as host immunity for different population is perhaps the key question at present. 


\section{CONCLUSION}

H. pylori infection is the major risk factor for peptic ulcer and gastric cancer and the eradication of this bacterium using antibiotics is often unsuccessful. Several microbes with known probiotic activities are shown to have inhibitory effects against $H$. pylori in vitro and in vivo. Inclusion of probiotics in triple therapy leads to improved efficacy and reduced side effects. Most traditional fermented foods and beverages are natural sources of probiotic microbes. Microbes directly isolated from the fermented products are shown to have antiH. pylori activity. Few studies showed that consumption of probiotics containing yogurt and kefir are somewhat beneficial in the context of $H$. pylori infection. Many ethnic populations have significantly low incidences of peptic ulcer and gastric cancer in spite of having very high prevalence of $H$. pylori infection. Incidentally, each ethnic population also has unique tradition of consuming fermented food and beverages that contain probiotics. It is intriguing to hypothesize that regular

\section{REFERENCES}

Abriouel, H., Omar, N. B., López, R. L., Martínez-Cañamero, M., Keleke, S., and Gálvez, A. (2006). Culture-independent analysis of the microbial composition of the African traditional fermented foods poto poto and dégué by using three different DNA extraction methods. Int. J. Food Microbiol. 111, 228-233. doi: 10.1016/j.ijfoodmicro.2006.06.006

Andersson, A. F., Lindberg, M., Jakobsson, H., Backhed, F., Nyren, P., and Engstrand, L. (2008). Comparative analysis of human gut microbiota by barcoded pyrosequencing. PLoS ONE 3:e2836. doi: 10.1371/journal.pone.0002836

Aoki, H., Uda, I., Tagami, K., Furuya, Y., Endo, Y., and Fujimoto, K. (2003). The production of a new tempeh-like fermented soybean containing a high level of $\gamma$-aminobutyric acid by anaerobic incubation with Rhizopus. Biosci. Biotechnol. Biochem. 67, 1018-1023. doi: 10.1271/bbb.67.1018

Armuzzi, A., Cremonini, F., Bartolozzi, F., Canducci, F., Candelli, M., Ojetti, V., et al. (2001). The effect of oral administration of Lactobacillus GG on antibiotic-associated gastrointestinal side-effects during Helicobacter pylori eradication therapy. Aliment. Pharmacol. Ther. 15, 163-169. doi: 10.1046/j.1365-2036.2001.00923.x

Atherton, J. C., Cao, P., Peek, R. M. Jr., Tummuru, M. K., Blaser, M. J., and Cover, T. L. (1995). Mosaicism in vacuolating cytotoxin alleles of Helicobacter pylori. Association of specific vacA types with cytotoxin production and peptic ulceration. J. Biol. Chem. 270, 17771-17777. doi: 10.1074/jbc.270.30. 17771

Atherton, J. C., Cover, T. L., Twells, R. J., Morales, M. R., Hawkey, C. J., and Blaser, M. J. (1999). Simple and accurate PCR-based system for typing vacuolating cytotoxin alleles of Helicobacter pylori. J. Clin. Microbiol. 37, 2979-2982.

Avía, Y., Suzuki, N., Kabir, A., Takagi, A., and Koga, Y. (1998). Lactic acidmediated suppression of Helicobacter pylori by the oral administration of Lactobacillus salivarius as a probiotic in a gnotobiotic murine model. Am. J. Gastroenterol. 93, 2097-2101. doi: 10.1111/j.1572-0241.1998.00600.x

Bekar, O., Yilmaz, Y., and Gulten, M. (2011). Kefir improves the efficacy and tolerability of triple therapy in eradicating Helicobacter pylori. J. Med. Food 14, 344-347. doi: 10.1089/jmf.2010.0099

Bhatia, S. J., Kochar, N., Abraham, P., Nair, N. G., and Mehta, A. P. (1989). Lactobacillus acidophilus inhibits growth of Campylobacter pylori in vitro. J. Clin. Microbiol. 27, 2328-2330.

Blaser, M. J. (2008). Disappearing microbiota: Helicobacter pylori protection against esophageal adenocarcinoma. Cancer Prev. Res. (Phila) 1, 308-311. doi: 10.1158/1940-6207.CAPR-08-0170

Blaser, M. J., and Falkow, S. (2009). What are the consequences of the disappearing human microbiota? Nat. Rev. Microbiol. 7, 887-894. doi: 10.1038/nrmicro2245 consumptions of these probiotics may have protective effect against peptic ulcer and gastric cancer for some populations. Analyzing these traditional fermented foods and beverages using modern techniques is needed to understand these microbes and their significances.

\section{AUTHOR CONTRIBUTIONS}

$\mathrm{MN}$ and DC equally contributed $60 \%$ of the mini-review works. SG contributed $15 \%$ and SC contributed $25 \%$ in the mini-review works.

\section{FUNDING}

This work was supported by Rajiv Gandhi Centre for Biotechnology (an autonomous institute, sponsored by Department of Biotechnology, Govt. of India).

Blaser, M. J., Perez-Perez, G. I., Kleanthous, H., Cover, T. L., Peek, R. M., Chyou, P. H., et al. (1995). Infection with Helicobacter pylori strains possessing cagA is associated with an increased risk of developing adenocarcinoma of the stomach. Cancer Res. 55, 2111-2115.

Campbell-Platt, G. (1987). Fermented Foods of the World. A Dictionary and Guide. London: Butterworths.

Chen, X., Tian, F., Liu, X., Zhao, J., Zhang, H.-P., Zhang, H., et al. (2010). In vitro screening of lactobacilli with antagonistic activity against Helicobacter pylori from traditionally fermented foods. J. Dairy Sci. 93, 5627-5634. doi: 10.3168/jds.2010-3449

Chmielewska, A., and Szajewska, H. (2010). Systematic review of randomised controlled trials: probiotics for functional constipation. World J. Gastroenterol. 16, 69-75.

Covacci, A., Telford, J. L., Del Giudice, G., Parsonnet, J., and Rappuoli, R. (1999). Helicobacter pylori virulence and genetic geography. Science 284, 1328-1333. doi: $10.1126 /$ science.284.5418.1328

Cover, T. L., Tummuru, M. K., Cao, P., Thompson, S. A., and Blaser, M. J. (1994). Divergence of genetic sequences for the vacuolating cytotoxin among Helicobacter pylori strains. J. Biol. Chem. 269, 10566-10573.

Dajani, A. I., Hammour, A. M. A., Yang, D. H., Chung, P. C., Nounou, M. A., Yuan, K. Y., et al. (2013). Do probiotics improve eradication response to Helicobacter pylori on standard triple or sequential therapy? Saudi J. Gastroenterol. 19:113120. doi: 10.4103/1319-3767.111953

Dang, Y., Reinhardt, J. D., Zhou, X., and Zhang, G. (2014). The effect of probiotics supplementation on Helicobacter pylori eradication rates and side effects during eradication therapy: a meta-analysis. PLoS ONE 9:e111030. doi: 10.1371/journal.pone.0111030

Datta, S., Chattopadhyay, S., Nair, G. B., Mukhopadhyay, A. K., Hembram, J., Berg, D. E., et al. (2003). Virulence genes and neutral DNA markers of Helicobacter pylori isolates from different ethnic communities of West Bengal, India. J. Clin. Microbiol. 41, 3737-3743. doi: 10.1128/JCM.41.8.3737-3743.2003

Datta De, D., and Roychoudhury, S. (2015). To be or not to be: the host genetic factor and beyond in Helicobacter pylori mediated gastro-duodenal diseases. World J. Gastroenterol. 21, 2883-2895. doi: 10.3748/wjg.v21.i10.2883

De, D. D., and Roychoudhury, S. (2015). To be or not to be: the host genetic factor and beyond in Helicobacter pylori mediated gastro-duodenal diseases. World J. Gastroenterol. 21, 2883-2895. doi: 10.3748/wjg.v21.i10.2883

De Filippo, C., Cavalieri, D., Di Paola, M., Ramazzotti, M., Poullet, J. B., Massart, S., et al. (2010). Impact of diet in shaping gut microbiota revealed by a comparative study in children from Europe and rural Africa. Proc. Natl. Acad. Sci. U.S.A. 107, 14691-14696. doi: 10.1073/pnas.1005963107

Deguchi, R., Nakaminami, H., Rimbara, E., Noguchi, N., Sasatsu, M., Suzuki, T., et al. (2012). Effect of pretreatment with Lactobacillus gasseri OLL2716 on 
first-line Helicobacter pylori eradication therapy. J. Gastroenterol. Hepatol. 27, 888-892. doi: 10.1111/j.1440-1746.2011.06985.x

Doenges, J. L. (1938). Spirochetes in gastric glands of Macacus rhesus and humans without definite history of related disease. Exp. Biol. Med. 38, 536-538. doi: 10.3181/00379727-38-9924P

Dore, M. P., Cuccu, M., Pes, G. M., Manca, A., and Graham, D. Y. (2014). Lactobacillus reuteri in the treatment of Helicobacter pylori infection. Intern. Emerg. Med. 9, 649-654. doi: 10.1007/s11739-013-1013-z

Dorer, M. S., Talarico, S., and Salama, N. R. (2009). Helicobacter pylori's unconventional role in health and disease. PLoS Pathog. 5:e1000544. doi: 10.1371/journal.ppat.1000544

El-Omar, E. M. (2001). The importance of interleukin 1beta in Helicobacter pylori associated disease. Gut 48, 743-747. doi: 10.1136/gut.48.6.743

Enany, S., and Abdalla, S. (2015). In vitro antagonistic activity of Lactobacillus casei against Helicobacter pylori. Braz. J. Microbiol. 46, 1201-1206. doi: $10.1590 /$ S1517-838246420140675

Fijan, S. (2014). Microorganisms with claimed probiotic properties: an overview of recent literature. Int. J. Environ. Res. Public Health 11, 4745-4767. doi: 10.3390/ijerph110504745

Francavilla, R., Lionetti, E., Castellaneta, S. P., Magistà, A. M., Maurogiovanni, G., Bucci, N., et al. (2008). Inhibition of Helicobacter pylori infection in humans by Lactobacillus reuteri ATCC 55730 and effect on eradication therapy: a pilot study. Helicobacter 13, 127-134. doi: 10.1111/j.1523-5378.2008.00593.x

Francavilla, R., Polimeno, L., Demichina, A., Maurogiovanni, G., Principi, B., Scaccianoce, G., et al. (2014). Lactobacillus reuteri strain combination in Helicobacter pylori infection: a randomized, doubleblind, placebo-controlled study. J. Clin. Gastroenterol. 48, 407-413. doi: 10.1097/MCG.0000000000000007

Freedberg, A. S., and Barron, L. E. (1940). The presence of spirochetes in human gastric mucosa. Am. J. Dig. Dis. 7, 443-445. doi: 10.1007/BF02997393

Galmiche, A., Rassow, J., Doye, A., Cagnol, S., Chambard, J. C., Contamin, S., et al. (2000). The $\mathrm{N}$-terminal $34 \mathrm{kDa}$ fragment of Helicobacter pylori vacuolating cytotoxin targets mitochondria and induces cytochrome c release. EMBO J. 19, 6361-6370. doi: 10.1093/emboj/19.23.6361

Gebert, B., Fischer, W., Weiss, E., Hoffmann, R., and Haas, R. (2003). Helicobacter pylori vacuolating cytotoxin inhibits T lymphocyte activation. Science 301, 1099-1102. doi: 10.1126/science. 1086871

Ghrairi, T., Manai, M., Berjeaud, J., and Frere, J. (2004). Antilisterial activity of lactic acid bacteria isolated from rigouta, a traditional Tunisian cheese. J. Appl. Microbiol. 97, 621-628. doi: 10.1111/j.1365-2672.2004.02347.x

Haruta, S., Ueno, S., Egawa, I., Hashiguchi, K., Fujii, A., Nagano, M., et al. (2006). Succession of bacterial and fungal communities during a traditional pot fermentation of rice vinegar assessed by PCR-mediated denaturing gradient gel electrophoresis. Int. J. Food Microbiol. 109, 79-87. doi: 10.1016/j.ijfoodmicro.2006.01.015

Hatakeyama, M. (2014). Helicobacter pylori CagA and gastric cancer: a paradigm for hit-and-run carcinogenesis. Cell Host Microbe 15, 306-316. doi: 10.1016/j.chom.2014.02.008

Hempel, S., Newberry, S. J., Maher, A. R., Wang, Z., Miles, J. N., Shanman, R., et al. (2012). Probiotics for the prevention and treatment of antibiotic-associated diarrhea: a systematic review and meta-analysis. JAMA 307, 1959-1969. doi: 10.1001/jama.2012.3507

Higashi, H., Tsutsumi, R., Muto, S., Sugiyama, T., Azuma, T., Asaka, M., et al. (2002). SHP-2 tyrosine phosphatase as an intracellular target of Helicobacter pylori CagA protein. Science 295, 683-686. doi: 10.1126/science.1067147

Hirayama, T. (1981). Relationship of soybean paste soup intake to gastric cancer risk. Nutr. Cancer 3, 223-233.

Holcombe, C. (1992). Helicobacter pylori: the African enigma. Gut 33, 429-431. doi: 10.1136/gut.33.4.429

Imase, K., Tanaka, A., Tokunaga, K., Sugano, H., Ishida, H., and Takahashi, S. (2007). Lactobacillus reuteri tablets suppress Helicobacter pylori infectiona double-blind randomised placebo-controlled cross-over clinical study. Kansenshogaku zasshi 81, 387-393.

Isolauri, E., Rautava, S., and Salminen, S. (2012). Probiotics in the development and treatment of allergic disease. Gastroenterol. Clin. North Am. 41, 747-762. doi: 10.1016/j.gtc.2012.08.007

Johnson-Henry, K. C., Mitchell, D. J., Avitzur, Y., Galindo-Mata, E., Jones, N. L., and Sherman, P. M. (2004). Probiotics reduce bacterial colonization and gastric inflammation in H. pylori-infected mice. Dig. Dis. Sci. 49, 1095-1102. doi: 10.1023/B:DDAS.0000037794.02040.c2

Kabir, A., Aiba, Y., Takagi, A., Kamiya, S., Miwa, T., and Koga, Y. (1997). Prevention of Helicobacter pylori infection by lactobacilli in a gnotobiotic murine model. Gut 41, 49-55. doi: 10.1136/gut.41.1.49

Kienesberger, S., Cox, L. M., Livanos, A., Zhang, X.-S., Chung, J., Perez-Perez, G. I., et al. (2016). Gastric Helicobacter pylori infection affects local and distant microbial populations and host responses. Cell Rep. 14, 1395-1407. doi: 10.1016/j.celrep.2016.01.017

Kim, S.-Y., Yoo, K.-S., Kim, J. E., Kim, J.-S., Jung, J. Y., Jin, Q., et al. (2010). Diversity analysis of lactic acid bacteria in Korean rice wines by cultureindependent method using PCR-denaturing gradient gel electrophoresis. Food Sci. Biotechnol. 19, 749-755. doi: 10.1007/s10068-010-0105-z

Kiyohara, M., Koyanagi, T., Matsui, H., Yamamoto, K., Take, H., Katsuyama, Y., et al. (2012). Changes in microbiota population during fermentation of narezushi as revealed by pyrosequencing analysis. Biosci. Biotechnol. Biochem. 76, 48-52. doi: 10.1271/bbb.110424

Kostinek, M., Specht, I., Edward, V. A., Schillinger, U., Hertel, C., Holzapfel, W. H., et al. (2005). Diversity and technological properties of predominant lactic acid bacteria from fermented cassava used for the preparation of Gari, a traditional African food. System. Appl. Microbiol. 28, 527-540. doi: 10.1016/j.syapm.2005.03.001

Kubo, Y., Rooney, A. P., Tsukakoshi, Y., Nakagawa, R., Hasegawa, H., and Kimura, K. (2011). Phylogenetic analysis of Bacillus subtilis strains applicable to natto (fermented soybean) production. Appl. Environ. Microbiol. 77, 64636469. doi: 10.1128/AEM.00448-11

Kumar, V., and Rao, R. (2007). Some interesting indigenous beverages among the tribal of Central India. Indian J. Tradit. Knowl. 6, 141-143.

Lederberg, J. (2001). 'Ome Sweet' Omics- a genealogical treasury of words. Scientist 15:8.

Leunk, R. D., Johnson, P. T., David, B. C., Kraft, W. G., and Morgan, D. R. (1988), Cytotoxic activity in broth-culture filtrates of Campylobacter pylori. J. Med. Microbiol. 26, 93-99. doi: 10.1099/00222615-26-2-93

Lin, W. H., Wu, C. R., Fang, T. J., Guo, J. T., Huang, S. Y., Lee, M. S., et al. (2011). Anti-Helicobacter pylori activity of fermented milk with lactic acid bacteria. J. Sci. Food Agric. 91, 1424-1431. doi: 10.1002/jsfa.4327

Lorca, G. L., Wadström, T., De Valdez, G. F., and Ljungh, ̊̊ (2001). Lactobacillus acidophilus autolysins inhibit Helicobacter pylori in vitro. Curr. Microbiol. 42, 39-44. doi: 10.1007/s002840010175

Mackowiak, P. A. (2013). Recycling metchnikoff: probiotics, the intestinal microbiome and the quest for long life. Front Public Health 1:52. doi: 10.3389/fpubh.2013.00052

Maldonado-Contreras, A., Goldfarb, K. C., Godoy-Vitorino, F., Karaoz, U., Contreras, M., Blaser, M. J., et al. (2011). Structure of the human gastric bacterial community in relation to Helicobacter pylori status. ISME J. 5, 574-579. doi: 10.1038/ismej.2010.149

Malfertheiner, P., Link, A., and Selgrad, M. (2014). Helicobacter pylori: perspectives and time trends. Nat. Rev. Gastroenterol. Hepatol. 11, 628-638. doi: 10.1038/nrgastro.2014.99

Malnick, S., Melzer, E., Attali, M., Duek, G., and Yahav, J. (2014). Helicobacter pylori: friend or foe. World J. Gastroenterol. 20, 8979-8985. doi: 10.3748/wjg.v20.i27.8979

Marshall, B., and Warren, J. R. (1984). Unidentified curved bacilli in the stomach of patients with gastritis and peptic ulceration. Lancet 323, 1311-1315. doi: 10.1016/S0140-6736(84)91816-6

Marshall, B. J., Armstrong, J. A., Mcgechie, D. B., and Glancy, R. J. (1985). Attempt to fulfil Koch's postulates for pyloric Campylobacter. Med. J. Aust. 142, 436-439.

Mathara, J. M., Schillinger, U., Kutima, P. M., Mbugua, S. K., and Holzapfel, W. H. (2004). Isolation, identification and characterisation of the dominant microorganisms of kule naoto: the Maasai traditional fermented milk in Kenya. Int. J. Food Microbiol. 94, 269-278. doi: 10.1016/j.ijfoodmicro.2004. 01.008

McFarland, L. V. (2007). Meta-analysis of probiotics for the prevention of traveler's diarrhea. Travel Med. Infect. Dis. 5, 97-105. doi: 10.1016/j.tmaid.2005. 10.003

McGovern, P. E., Zhang, J., Tang, J., Zhang, Z., Hall, G. R., Moreau, R. A., et al. (2004). Fermented beverages of pre-and proto-historic China. Proc. Natl. Acad. Sci. U.S.A. 101, 17593-17598. doi: 10.1073/pnas.0407921102 
Midolo, P., Lambert, J., Hull, R., Luo, F., and Grayson, M. (1995). In vitro inhibition of Helicobacter pylori NCTC 11637 by organic acids and lactic acid bacteria. J. Appl. Bacteriol. 79, 475-479. doi: 10.1111/j.1365-2672.1995.tb03164.x

Mozzi, F., Ortiz, M. E., Bleckwedel, J., De Vuyst, L., and Pescuma, M. (2013). Metabolomics as a tool for the comprehensive understanding of fermented and functional foods with lactic acid bacteria. Food Res. Int. 54, 1152-1161. doi: 10.1016/j.foodres.2012.11.010

Mukai, T., Asasaka, T., Sato, E., Mori, K., Matsumoto, M., and Ohori, H. (2002). Inhibition of binding of Helicobacter pylori to the glycolipid receptors by probiotic Lactobacillus reuteri. FEMS Immunol. Med. Microbiol. 32, 105-110. doi: 10.1111/j.1574-695X.2002.tb00541.x

Naghavi, M., Wang, H., Lozano, R., Davis, A., Liang, X., Zhou, M., et al. (2015). Global, regional, and national age-sex specific all-cause and cause-specific mortality for 240 causes of death, 1990-2013: a systematic analysis for the Global Burden of Disease Study 2013. Lancet 385, 117-171. doi: 10.1016/S01406736(14)61682-2

Nam, H., Ha, M., Bae, O., and Lee, Y. (2002). Effect of Weissella confusa strain PL9001 on the adherence and growth of Helicobacter pylori. Appl. Environ. Microbiol. 68, 4642-4645. doi: 10.1128/AEM.68.9.4642-4645. 2002

Nanda, K., Taniguchi, M., Ujike, S., Ishihara, N., Mori, H., Ono, H., et al. (2001). Characterization of acetic acid bacteria in traditional acetic acid fermentation of rice vinegar (komesu) and unpolished rice vinegar (kurosu) produced in Japan. Appl. Environ. Microbiol. 67, 986-990. doi: 10.1128/AEM.67.2.986-990. 2001

Oh, Y., Osato, M., Han, X., Bennett, G., and Hong, W. (2002). Folk yoghurt kills Helicobacter pylori. J. Appl. Microbiol. 93, 1083-1088. doi: 10.1046/j.13652672.2002.01779.x

Olasupo, N., Olukoya, D., and Odunfa, S. (1997). Identification of Lactobacillus species associated with selected African fermented foods. Z. Naturforsch. C 52, 105-108. doi: 10.1016/j.imbio.2013.10.005

Ornelas, I. J., Galvan-Potrillo, M., and López-Carrillo, L. (2007). Protective effect of yoghurt consumption on Helicobacter pylori seropositivity in a Mexican population. Public Health Nutr. 10, 1283-1287. doi: $10.1017 /$ S1368980007696372

Parekh, P. J., Balart, L. A., and Johnson, D. A. (2014). The influence of the gut microbiome on obesity, metabolic syndrome and gastrointestinal disease. Clin. Transl. Gastroenterol. 6, e91. doi: 10.1038/ctg.2015.16

Phukan, R. K., Zomawia, E., Narain, K., Hazarika, N. C., and Mahanta, J. (2005). Tobacco use and stomach cancer in Mizoram, India. Cancer Epidemiol. Biomarkers Prev. 14, 1892-1896. doi: 10.1158/1055-9965.EPI-05-0074

Piazuelo, M. B., and Correa, P. (2013). Gastric cancer: overview. Colomb. Med. (Cali) 44, 192-201.

Pradhan, H., Verma, Y., and Pradhan, P. (2003-2004). POPULATION BASED CANCER REGISTRY, SIKKIM STATE-Sir Thutob Namgyal Memorial Hospital, Gangtok. Gangtok: Gangtok Sir Thutob Namgyal Memorial Hospital.

Reid, G. (1999). The scientific basis for probiotic strains of Lactobacillus. Appl. Environ. Microbiol. 65, 3763-3766.

Rhead, J. L., Letley, D. P., Mohammadi, M., Hussein, N., Mohagheghi, M. A., Hosseini, M. E., et al. (2007). A new Helicobacter pylori vacuolating cytotoxin determinant, the intermediate region, is associated with gastric cancer. Gastroenterology 133, 926-936. doi: 10.1053/j.gastro.2007.06.056

Rhee, S. J., Lee, J.-E., and Lee, C.-H. (2011). Importance of lactic acid bacteria in Asian fermented foods. Microbial Cell Fact. 10:S5. doi: 10.1186/1475-2859-10S1-S5

Rokka, S., Pihlanto, A., Korhonen, H., and Joutsjoki, V. (2006). In vitro growth inhibition of Helicobacter pylori by lactobacilli belonging to the Lactobacillus plantarum group. Lett. Appl. Microbiol. 43, 508-513. doi: 10.1111/j.1472765X.2006.01998.x

Ruggiero, P. (2014). Use of probiotics in the fight against Helicobacter pylori. World J. Gastrointest. Pathophysiol. 5, 384-391. doi: 10.4291/wjgp.v5.i4.384

Ruiz, L., Margolles, A., and Sánchez, B. (2013). Bile resistance mechanisms in Lactobacillus and Bifidobacterium. Front. Microbiol. 4:396. doi: 10.3389/fmicb.2013.00396

Russo, F., Linsalata, M., and Orlando, A. (2014). Probiotics against neoplastic transformation of gastric mucosa: effects on cell proliferation and polyamine metabolism. World J. Gastroenterol. 20, 13258-13272. doi: 10.3748/wjg.v20.i37.13258
Sachdeva, A., and Nagpal, J. (2009). Effect of fermented milk-based probiotic preparations on Helicobacter pylori eradication: a systematic review and metaanalysis of randomized-controlled trials. Eur. J. Gastroenterol. Hepatol. 21, 45-53. doi: 10.1097/MEG.0b013e32830d0eff

Saggioro, A., Caroli, M., Pasini, M., Bortoluzzi, F., Girardi, L., and Pilone, G. (2005). Helicobacter pylori eradication with Lactobacillus reuteri. A doubleblind placebo-controlled study. Dig. Liver Dis. 37:S88.

Sakaguchi, K. (1958a). Studies on the activities of bacteria in soy sauce brewing. Bull. Agric. Chem. Soc. Japan 22, 345-352. doi: 10.1271/bbb1924.22.353

Sakaguchi, K. (1958b). Studies on the activities of bacteria in soy sauce brewing: Part II. The proteinases and the existence of Bacilli Spores in the Soy Mash Part III. Taxonomic studies on Pediococcus soyae nov. sp., the Soy Sauce Lactic Acid Bacteria. J. Agric. Chem. Soc. Japan 22, 345-362.

Sakamoto, I., Igarashi, M., Kimura, K., Takagi, A., Miwa, T., and Koga, Y. (2001). Suppressive effect of Lactobacillus gasseri OLL 2716 (LG21) on Helicobacter pylori infection in humans. J. Antimicrob. Chemother. 47, 709-710. doi: 10.1093/jac/47.5.709

Sgouras, D., Maragkoudakis, P., Petraki, K., Martinez-Gonzalez, B., Eriotou, E., Michopoulos, S., et al. (2004). In vitro and in vivo inhibition of Helicobacter pylori by Lactobacillus casei strain Shirota. Appl. Environ. Microbiol. 70, 518526. doi: 10.1128/AEM.70.1.518-526.2004

Shiota, S., Murakawi, K., Suzuki, R., Fujioka, T., and Yamaoka, Y. (2013). Helicobacter pylori infection in Japan. Expert Rev. Gastroenterol. Hepatol. 7 , 35-40. doi: 10.1586/egh.12.67

Singh, K., and Ghoshal, U. C. (2006). Causal role of Helicobacter pylori infection in gastric cancer: an Asian enigma. World J. Gastroenterol. 12, 1346-1351. doi: 10.3748/wjg.v12.i9.1346

Stanton, C., Ross, R. P., Fitzgerald, G. F., and Van Sinderen, D. (2005). Fermented functional foods based on probiotics and their biogenic metabolites. Curr. Opin. Biotechnol. 16, 198-203. doi: 10.1016/j.copbio.2005.02.008

Tamang, J. P., Holzapfel, W. H., and Watabane, K. (2016a). Review: diversity of microorganisms in global fermented foods and beverages. Front. Microbiol. 7:377. doi: 10.3389/fmicb.2016.00377

Tamang, J. P., and Sarkar, P. K. (1996). Microbiology of mesu, a traditional fermented bamboo shoot product. Int. J. Food Microbiol. 29, 49-58. doi: 10.1016/0168-1605(95)00021-6

Tamang, J. P., Shin, D.-H., Jung, S.-J., and Chae, S.-W. (2016b). Functional properties of microorganisms in fermented foods. Front. Microbiol. 7:578. doi: 10.3389/fmicb.2016.00578

Torres, V. J., Vancompernolle, S. E., Sundrud, M. S., Unutmaz, D., and Cover, T. L. (2007). Helicobacter pylori vacuolating cytotoxin inhibits activationinduced proliferation of human T and B lymphocyte subsets. J. Immunol. 179, 5433-5440. doi: 10.4049/jimmunol.179.8.5433

Verma, Y., Pradhan, P. K., Gurung, N., Sapkota, S. D., Giri, P., Sundas, P., et al. (2012). Population-based cancer incidence in Sikkim, India: report on ethnic variation. Br. J. Cancer 106, 962-965. doi: 10.1038/bjc. 2011.598

Vilaichone, R., Mahachai, V., Tumwasorn, S., Nunthapisud, P., and Kullavanijaya, P. (2002). Inhibitory effect of Lactobacillus acidophilus on Helicobacter pylori in peptic ulcer patients: in vitro study. J. Med. Assoc. Thai. 85, S79-S84.

Wang, Z.-H., Gao, Q.-Y., and Fang, J.-Y. (2013). Meta-analysis of the efficacy and safety of Lactobacillus-containing and Bifidobacterium-containing probiotic compound preparation in Helicobacter pylori eradication therapy. J. Clin. Gastroenterol. 47, 25-32. doi: 10.1097/MCG.0b013e318266f6cf

Warren, J. R., and Marshall, B. (1983). Unidentified curved bacilli on gastric epithelium in active chronic gastritis. Lancet 321, 1273-1275. doi: 10.1016/S0140-6736(83)92719-8

Willhite, D. C., and Blanke, S. R. (2004). Helicobacter pylori vacuolating cytotoxin enters cells, localizes to the mitochondria, and induces mitochondrial membrane permeability changes correlated to toxin channel activity. Cell Microbiol. 6, 143-154. doi: 10.1046/j.1462-5822.2003. 00347.x

Woo, H. D., Park, S., Oh, K., Kim, H. J., Shin, H. R., Moon, H. K., et al. (2013). Diet and cancer risk in the Korean population: a meta-analysis. Asian Pac. J. Cancer Prev. 15, 8509-8519. doi: 10.7314/APJCP.2014.15.19.8509

Xiang, Z., Censini, S., Bayeli, P. F., Telford, J. L., Figura, N., Rappuoli, R., et al. (1995). Analysis of expression of CagA and VacA virulence factors in 43 strains 
of Helicobacter pylori reveals that clinical isolates can be divided into two major types and that CagA is not necessary for expression of the vacuolating cytotoxin. Infect. Immun. 63, 94-98.

Yamaoka, Y. (2010). Mechanisms of disease: Helicobacter pylori virulence factors. Nat. Rev. Gastroenterol. Hepatol. 7, 629-641. doi: 10.1038/nrgastro. 2010.154

Yamaoka, Y., Kodama, T., Kashima, K., Graham, D. Y., and Sepulveda, A. R. (1998). Variants of the $3^{\prime}$ region of the cagA gene in Helicobacter pylori isolates from patients with different $H$. pylori-associated diseases. J. Clin. Microbiol. 36, 2258-2263.

Yamasaki, E., Wada, A., Kumatori, A., Nakagawa, I., Funao, J., Nakayama, M., et al. (2006). Helicobacter pylori vacuolating cytotoxin induces activation of the proapoptotic proteins Bax and Bak, leading to cytochrome c release and cell death, independent of vacuolation. J. Biol. Chem. 281, 11250-11259. doi: 10.1074/jbc.M509404200

Yang, Y.-J., Chuang, C.-C., Yang, H.-B., Lu, C.-C., and Sheu, B.-S. (2012). Lactobacillus acidophilus ameliorates $\mathrm{H}$. pylori-induced gastric inflammation by inactivating the Smad7 and NFkB pathways. BMC Microbiol. 12:38. doi: 10.1186/1471-2180-12-38

Yang, Y. J., and Sheu, B. S. (2012). Probiotics-containing yogurts suppress Helicobacter pylori load and modify immune response and intestinal microbiota in the Helicobacter pylori-infected children. Helicobacter 17, 297-304. doi: 10.1111/j.1523-5378.2012.00941.x

Zhang, M.-M., Qian, W., Qin, Y.-Y., He, J., and Zhou, Y.-H. (2015). Probiotics in Helicobacter pylori eradication therapy: a systematic review and meta-analysis. World J. Gastroenterol. 21:4345. doi: 10.3748/wjg.v21.i14.4345

Zheng, X., Lyu, L., and Mei, Z. (2013). Lactobacillus-containing probiotic supplementation increases Helicobacter pylori eradication rate: evidence from a meta-analysis. Rev. Esp. Enferm. Dig. 105, 445-453. doi: 10.4321/S113001082013000800002

Conflict of Interest Statement: The authors declare that the research was conducted in the absence of any commercial or financial relationships that could be construed as a potential conflict of interest.

Copyright $\odot 2016$ Nair, Chouhan, Sen Gupta and Chattopadhyay. This is an openaccess article distributed under the terms of the Creative Commons Attribution License (CC BY). The use, distribution or reproduction in other forums is permitted, provided the original author(s) or licensor are credited and that the original publication in this journal is cited, in accordance with accepted academic practice. No use, distribution or reproduction is permitted which does not comply with these terms. 